This item was submitted to Loughborough's Research Repository by the author.

Items in Figshare are protected by copyright, with all rights reserved, unless otherwise indicated.

\title{
Inactivation of water pathogens with solar photo-activated persulfate oxidation
}

PLEASE CITE THE PUBLISHED VERSION

PUBLISHER

Elsevier

VERSION

AM (Accepted Manuscript)

PUBLISHER STATEMENT

This paper was accepted for publication in the journal Chemical Engineering Journal and the definitive published version is available at https://doi.org/10.1016/j.cej.2019.122275.

\section{LICENCE}

CC BY-NC-ND 4.0

\section{REPOSITORY RECORD}

Ferreira, LC, M Castro-Alférez, S Nahim-Granados, MI Polo-López, MS Lucas, Gianluca Li-Puma, and P Fernández-Ibáñez. 2019. "Inactivation of Water Pathogens with Solar Photo-activated Persulfate Oxidation". figshare. https://hdl.handle.net/2134/9917714.v1. 


\section{Inactivation of water pathogens with solar photo-activated persulfate oxidation}

L. C. Ferreira ${ }^{\mathrm{a}}$, M. Castro-Alférez ${ }^{\mathrm{b}}$, S. Nahim-Granados ${ }^{\mathrm{b}}$, M.I. Polo-López ${ }^{\mathrm{b}}$, M. S. Lucas $^{\mathrm{a}, \mathrm{c}^{*}}$, G. Li Puma ${ }^{\mathrm{c}}$, P. Fernández-Ibáñez ${ }^{\mathrm{b}, \mathrm{d}}$

\footnotetext{
${ }^{a}$ Centro de Química de Vila Real, Universidade de Trás-os-Montes e Alto Douro, 5000-801 Vila Real, Portugal

b Plataforma Solar de Almería - CIEMAT, P.O. Box 22, 04200 Tabernas, Almería, Spain

${ }^{\mathrm{c}}$ Environmental Nanocatalysis \& Photoreaction Engineering, Department of Chemical Engineering, Loughborough University, Loughborough, LE11 3TU, United Kingdom d Nanotechnology and Integrated BioEngineering Centre, School of Engineering, University of Ulster, Newtownabbey, Northern Ireland BT37 0QB, United Kingdom
}

*Corresponding authors:

Marco S. Lucas; mlucas@utad.pt

Pilar Fernández-Ibáñez; p.fernandez@ulster.ac.uk 


\section{ABSTRACT}

The effect of solar activated persulfate oxidation and solar mild thermal heating on water disinfection (PS/solar) was demonstrated for the inactivation of E. coli and $E$. faecalis in both isotonic water (IW) and synthetic urban wastewater (SUWW). The process was studies in both bench-scale and pilot-scale (60 L CPC solar compound parabolic collector) reactors. The impact of solar ultraviolet (UV) and thermal increase on bacterial inactivation were separately studied. The thermal inactivation at $40{ }^{\circ} \mathrm{C}$ and $0.5 \mathrm{mM}$-PS shows a 3-log reduction value (LRV) for E. coli without lag phase and 5LRV for E. faecalis with a lag phase of $1 \mathrm{~h}$, during $4 \mathrm{~h}$ solar exposure. The thermal effect at $50{ }^{\circ} \mathrm{C}$ played a dominant role, with fast bacterial decay for both bacteria, which dominates the kinetics over the thermal activation of PS. In the presence of PS and solar irradiation, the combined thermal and UVA effects, accelerated the bacterial process. 6LRV in E. coli and E. faecalis was observed after solar exposure periods of $20 \mathrm{~min}$ (solar dose), using 0.5 and $0.7 \mathrm{mM}$ of PS in IW, respectively. Longer solar exposure times were required to attain similar LRV in synthetic urban wastewater, in the presence of $25 \mathrm{mg} / \mathrm{L}$ of organic matter, i.e. 80 and $100 \mathrm{~min}$ (solar dose) for E. coli and $E$. faecalis, respectively. These results were confirmed at pilot scale, where $60 \mathrm{~L}$ of IW were treated with $0.5 \mathrm{mM}$ of PS in $50 \mathrm{~min}$ (solar dose). The PS/solar process uses low cost chemical reagents ( $0.5 \mathrm{mM}-\mathrm{PS})$ and a free source of energy (solar radiation) for the treatment of wastewater and is able to achieve the high removals (6-LRV) of the two model faecal indicators of water contamination. This process opens a clear alternative to treat polluted water with organic matter and pathogens with implications in waterenergy reclamation field. 
Keywords: Compound Parabolic Collector; Persulfate; Solar UVA; Solar thermal; Sulfate radicals; Water disinfection.

\section{INTRODUCTION}

Today the world is suffering one of the worst crises in relation to fresh water sources, in terms of scarcity and quality. Usually water pollutants are organic contaminants, nutrients and waterborne pathogens, which have to be removed using conventional or new technologies to reduce health and environmental risks. The waterborne diseases triggered by pathogenic microorganisms pose a high threaten to human health and the environment. Therefore, water disinfection is a critical step to improve the quality of our water resources for a number of applications, i.e. irrigation, domestic use and to produce drinking water. In low income countries, the lack of clean and safe (free of pathogens) water is a major cause for the spread of waterborne diseases causing a high incidence of water related mortality and morbidity $[1,2]$.

Microbiological assessment of water quality is usually carried out through the measurement of the concentration of indicator microorganisms. Among these, Escherichia coli is the most commonly indicator of faecal contamination. E. coli is a Gram-negative coliform bacterium frequently present in untreated surface waters and in faecal contaminated water. Moreover, E. coli is recognised as the third most important pathogen responsible for childhood diarrhoea [3]. It is one of the most sensitive pathogen to disinfection techniques. Another frequently recognised indicator of faecal contamination is the Gram-positive bacterium Enterococcus faecalis, which is the most predominant intestinal enterococci [4]. This bacterium is highly present in the excreta of warm blooded animals and in polluted wastewater, while it is not present in clean 
waters or in any other sources that have not been in contact with human or animal life. Therefore, the World Health Organization has recommended the monitoring of $E$. faecalis as an indicator of faecal pollution in contaminated water. E. faecalis is usually more resistant than E. coli to most of the disinfection techniques or processes $[5,6]$.

Common water disinfection processes include chlorination, UV treatment using medium or low pressure mercury lamps and ozonation. These processes offer a strong capacity for the inactivation and killing of a wide range of pathogens in water, although they may also produce carcinogenic disinfection by-products such as trihalomethanes and haloacetic acids particularly in the presence of natural organic matter. UV and ozonation processes are very effective for the inactivation of a number of pathogens but, unlike chlorine, they do not possess residual disinfection capacity after treatment. The complexities associated with these technologies require high capital, operational and maintenance costs.

Recently, novel disinfection chemical and photo-chemical processes have been proposed as viable methods for water disinfection. In these processes, the photoexcitation of specific molecules and catalysts by photons produce of a number of strongly oxidising species (e.g., hydroxyl radicals, singlet oxygen and hydrogen peroxide) that will compromise the viability of water microorganisms, mostly via oxidative routes. These processes belong to the so-called advanced oxidation processes (AOPs), and include $\mathrm{H}_{2} \mathrm{O}_{2} / \mathrm{UVC}$, heterogeneous photocatalysis, photo-Fenton and $\mathrm{H}_{2} \mathrm{O}_{2} / \mathrm{O}_{3}$ [7-12]. Interestingly, some of these processes can be promoted by harvested solar radiation, which reduces energy consumption and the treatment cost. These are solar photo-induced processes [13], such as solar water disinfection [14], solar photocatalysis or solar photo-Fenton [15]. 
Sulfate radical-based advanced oxidation processes (SR-AOPs) are also highly efficient in the inactivation of pathogenic microorganisms in water [16-19]. Persulfate $\left(\mathrm{S}_{2} \mathrm{O}_{8}{ }^{2-}\right.$, PS) generates sulfate radicals $\left(\mathrm{SO}_{4}{ }^{--}\right)$which are able to damage cell structure and functions permanently. Additionally, PS is characterized by being stable at ambient temperature, having high solubility and non-toxicity [20-22]. The redox potential of $\mathrm{SO}_{4}{ }^{--}$varies between 2.5 and $3.1 \mathrm{~V}$ (pH dependent) and is close to the hydroxyl radical potential $\left(\mathrm{E}^{0}=1.8-2.7 \mathrm{~V}\right)$, which makes it a strong oxidant in water treatment [22-25]. The activation of PS with heat or UV radiation ends in the homolytic cleavage of the peroxide bond and the formation of two $\mathrm{SO}_{4}{ }^{--}$(reaction 1) [26].

$S_{2} \mathrm{O}_{8}^{2-} \stackrel{h v / \Delta T}{\longrightarrow} 2 \mathrm{SO}_{4}^{\bullet-}$

In situ chemical oxidation by PS is is a temperature dependant process, which tends to be less effective at temperatures below $20{ }^{\circ} \mathrm{C}$ [27]. The thermolytic generation of sulfate radicals was demonstrated at 30 and $37^{\circ} \mathrm{C}$ for the degradation of microcystin-LR [26]. The mineralization of bisphenol A by heat activated PS oxidation becomes more effective as the temperature was raised from 25 to $50{ }^{\circ} \mathrm{C}$ [28] and a 80 -fold rate increase in the oxidation of bisphenol A was observed as the temperature was increased from 40 to $70{ }^{\circ} \mathrm{C}$ [29]. Thus the activation of PS by temperature appears to be a very important operational parameter.

The UV activation of persulfate has been extensively explored with artificial sources of UVA-vis and UVC radiation. In general, the generation of sulfate radicals increases at lower wavelengths, which is related to the the higher extinction coefficients of PS at lower UV wavelengths (i.e., $\lambda_{\mathrm{PS}}=248 \mathrm{~nm}, \varepsilon_{\mathrm{PS}}=27.5 \mathrm{M}^{-1} \mathrm{~cm}^{-1} ; \lambda_{\mathrm{PS}}=308 \mathrm{~nm}, \varepsilon_{\mathrm{PS}}=$ $1.18 \mathrm{M}^{-1} \mathrm{~cm}^{-1} ; \lambda_{\mathrm{PS}}=351 \mathrm{~nm}, \varepsilon_{\mathrm{PS}}=0.25 \mathrm{M}^{-1} \mathrm{~cm}^{-1}$ ) [30]. Sulfate radicals have low 
absorption coefficients in the UV-vis spectra $\left(\overline{\lambda_{S O_{4}}}=450 \mathrm{~nm}, \overline{\varepsilon_{S O_{4}}}=1100 \mathrm{M}^{-1} \mathrm{~cm}^{-1}\right.$; $\left.\lambda_{S O_{5}}=260 \mathrm{~nm}, \varepsilon_{S O_{5}}=1030 \mathrm{M}^{-1} \mathrm{~cm}^{-1} ; \lambda_{\mathrm{SO}_{3}}=250 \mathrm{~nm}, \overline{\varepsilon_{S O_{3}}}=1380 \mathrm{M}^{-1} \mathrm{~cm}^{-1}\right)$ and brief half-life time $\left(t_{1 / 2}=30\right.$ to $\left.40 \mu \mathrm{s}\right)$. The highest absorption rate occurs in the UVC range, between 200 and $254 \mathrm{~nm}$, yet PS can be activated between 193 and $351 \mathrm{~nm}$, being possible to attain even higher absorption values when the oxidant concentrations are above mM levels [26,31]. Despite the low absorbance values, radiation is able to activate PS due to the high quantum yield at low wavelength values. The quantum yields formation of $\mathrm{SO}_{4}{ }^{--}$by the photolysis fission of PS have been reported as follows: $\lambda=248, \Phi=1.4 \pm 0.3 ; \lambda=308, \Phi=1.1 \pm 0.2 ; \lambda=351, \Phi=0.5 \pm 0.1[32]$.

SR-AOPs disinfection efficiency has been reported in several studies reporting different activation pathways $[6,17,25,33,34]$. The elimination of Enterococcus faecalis after 180 minutes was demonstrated using PS $(0.5 \mathrm{mM})$ activated with $\mathrm{Fe}^{3+} /$ EDDS (S,SEthylenediamine- $\mathrm{N}, \mathrm{N}^{\prime}$-disuccinic acid trisodium salt solution, $0.1 \mathrm{mM}$ ) and visible light [6]. Another study has shown the complete removal of E. coli in 20 minutes (6-LRV) using a catalyst and a white LED lamp for PS activation by the ilmenite/PS/vis system (1 g/L:0.5 mM:3 mW/cm²) [34]. Heat, solar UV (Xenon lamp with infrared and UV-C, $\left.900 \mathrm{~W} / \mathrm{m}^{2}\right)$ and $\mathrm{Fe}^{2+}(1 \mathrm{mg} / \mathrm{L})$ in PS activation were evaluated using MS2 bacteriophage and $E$. coli $\mathrm{K} 12$ as targets. In $E$. coli $\mathrm{K} 12$, the solar $\mathrm{UV}-\mathrm{C}$ activation was the most effective PS activator (6-LRV log decay in 180 minutes), while the combination of heat/solar UV-C/Fe ${ }^{2+}$ could attained a higher synergistic factor (2.21) with 6-LRV in 60 minutes, using $0.09 \mathrm{mM}$ of PS and $\mathrm{T}=40^{\circ} \mathrm{C}$. Heat activation $\left(30,40\right.$ and $\left.50^{\circ} \mathrm{C}\right)$ of PS revealed that only the higher temperature was able to properly inactivate the microorganism [25].

This study investigates the inactivation of E. coli and E. faecalis in isotonic water (IW) and synthetic urban wastewater (SUWW) by PS activated with direct solar radiation. 
The activation of PS by (i) natural solar radiation (PS/solar UVA) and by (ii) solar mild thermal heating (PS/solar thermal) was investigated at both bench and at pilot scale (60 L-solar Compound Parabolic Collector (CPC)), for the first time, as can be confirmed by Xiao and co-authors (2019) [35]. The basic effects of solar UV wavelengths and thermal increase have been separately studied for the inactivation of $E$. coli and $E$. faecalis. The process has been studied in isotonic water (IW) and synthetic urban wastewater (SUWW) at both laboratory and pilot scale (60 L-solar CPC reactor) under natural solar radiation.

\section{MATERIAL AND METHODS}

\subsection{Enumeration/quantification of bacteria}

E. coli (CECT 4624) and E. faecalis (CECT 5143) strains were obtained from the Spanish Type Culture Collection (CECT). Fresh liquid cultures were prepared in LuriaBertani nutrient medium (LB Broth) and incubated at $37^{\circ} \mathrm{C}$ with rotary shaking for $20 \mathrm{~h}$ $\left(10^{9} \mathrm{CFU} / \mathrm{mL}\right)$. The bacterial suspensions were centrifuged at $2500 \mathrm{rpm}$ for 10 minutes and the pellets were re-suspended in a phosphate-buffered saline (PBS) solution. The initial bacterial concentrations in the reactors were $10^{6} \mathrm{CFU} / \mathrm{mL}$. Samples were evaluated by the standard plate counting method using Slanetz Bartley agar for $E$. faecalis and Endo agar for E. coli. Serial 10-fold dilutions in PBS were made dropping $20 \mu \mathrm{L}$ (3 replicates) of each diluted sample over the corresponding agar medium. The detection limit was $17 \mathrm{CFU} / \mathrm{mL}(1 \mathrm{CFU}$ per $60 \mu \mathrm{L})$. The plates were incubated at $37{ }^{\circ} \mathrm{C}$ during $24 \mathrm{~h}$ for $E$. coli and $48 \mathrm{~h}$ for E. faecalis, prior to viable colonies count and enumeration calculations with statistical analysis.

\subsection{PS determination}


Sodium persulfate $\left(\mathrm{Na}_{2} \mathrm{~S}_{2} \mathrm{O}_{8}\right.$, Panreac) was measured according to an adapted spectrometric procedure described by Liang et al. (2008) using a T60 spectrometer, PG instruments [36]. In summary, $0.5 \mathrm{~mL}$ of sodium hydrogen carbonate $\left(\mathrm{NaHCO}_{3}\right.$, Sigma) was added to $1 \mathrm{~mL}$ of sample, $3.5 \mathrm{~mL}$ of potassium iodine (KI, Panreac) was also added at the same time; 15 minutes later, the optical absorption of the solution was measured at $352 \mathrm{~nm}$. The concentrations of PS used in this work were $0.01,0.05,0.1,0.2,0.5,0.7$ and $1 \mathrm{mM}$. This spectrophotometric method allows to differentiate between persulfate anion and sulfate radicals simultaneously. In order to evaluate the accuracy of this method, and considering that the ferrous iron is able to activate PS [25], a further experiment was made by adding persulfate and ferrous sulfate to water and by exposing to direct solar radiation for 1 hour. Simultaneously, the same experiment was made without ferrous sulfate (Figure S1). The concentrations were used in a proportion 1:5 as reported elsewhere [25]: $0.1 \mathrm{mM}$ of ferrous sulfate and 0.5 mM-PS. An additional dosage of $0.2 \mathrm{mM}$ of ferrous sulfate was also tested. The data clearly showed the activation of PS by ferrous sulfate when the values of persulfate anion are lowering during the experiment. In the case of UVA PS activation, the generation of radicals cannot be confirmed, since there was no difference in the values measured.

\subsection{Water matrices}

The E. coli and E. faecalis disinfection experiments were performed in two water matrices: isotonic water (IW) made of distilled water with sodium chloride $(0.9 \% \mathrm{w} / \mathrm{v})$ and synthetic urban wastewater (SUWW) which was prepared as described elsewhere [37]. This model wastewater was used to investigate the process under more realistic conditions. 


\subsection{Disinfection experiments}

The solar disinfection experiments were carried out at Plataforma Solar de Almería, Southeast of Spain, located at $37^{\circ} 84 \mathrm{~N}$ and $2^{\circ} 34 \mathrm{~W}$. Solar tests were performed in sunny days, in consecutive days during summer in 2 months, between 10:30 and 15:30, local time.

The reagents and the pathogens suspension were diluted into the reactor covered to obtain $10^{6} \mathrm{CFU} / \mathrm{mL}$ prior to solar exposure according to the following procedure. An appropriate dose of persulfate, when used, was added to the water matrix with the stirring on, followed by the bacterial suspension which was maintained under continuous stirring for $5 \mathrm{~min}$. After the collection of the first sample, the bacterial inactivation experiment started by exposing the reactor to solar light.

Samples collected from the reactor at regular intervals during the $5 \mathrm{~h}$ experiment were immediately diluted and analysed according to the aforementioned bacterial quantification methods. Each operational condition was tested in triplicate in consecutive days for similar solar irradiance. Results obtained from the replicates had high reproducibility ( $95 \%$ confidence level), and bacterial inactivation in each graph is represented as the average of the replicated with their corresponding standard deviation as error bar. The water temperature was monitored directly in the reactors using a thermometer (Checktemp, Hanna instruments).

\subsubsection{PS-thermal experiments (dark)}

A bacteria inactivation test in the dark in the presence of PS was performed to determine the effect of PS over the bacteria viability at room temperature $\left(25{ }^{\circ} \mathrm{C}\right)$. Moreover, the thermal activation of PS was investigated in a cool-hotter dry and dark incubator with $2 \mathrm{~mL}$ sterile containers (UniEquip $\mathrm{GmbH}$ ). The PS concentration used 
for thermal tests was $0.5 \mathrm{mM}$ as it was pre-selected due to the high inactivation rates obtained under solar radiation. Temperatures of 30,40 and $50{ }^{\circ} \mathrm{C}, \pm 0.5{ }^{\circ} \mathrm{C}$ were evaluated.

\subsubsection{Solar stirred tank reactors}

The bench scale solar experiments were performed with $200 \mathrm{~mL}$ in multiple $250 \mathrm{~mL}$ transparent vessels (DURAN-glass) magnetically stirred $(150 \mathrm{rpm})$ covered with Duran glass lids. A range of PS concentrations, 0.01, 0.05, 0.1, 0.2, 0.5, $0.7 \mathrm{mM}$ in IW and 0.2, 0.5, 0.7 and $1 \mathrm{mM}$ in SUWW, were evaluated. The reactors were exposed to natural solar radiation for 3 hours, in between 10:30 and 15:30.

\subsubsection{Solar Compound Parabolic Collector (CPC) reactor}

The pilot scale solar experiments were carried out in a recirculation batch system, comprising a Compound Parabolic Collector (CPC) reactor of $60 \mathrm{~L}$ (total volume) and $4.5 \mathrm{~m}^{2}$ of CPC area exposed to the sun (45 L of illuminated volume) at a $37^{\circ}$ angle, as described elsewhere [38]. The recirculation flow rate was $30 \mathrm{~L} / \mathrm{min}$ and the water temperature was controlled and maintained constant for the duration of the experiments using a heating-cooling system adapted to this reactor.

\subsection{Solar radiation measurements}

A solar UV pyranometer (CUV4, Kipp \& Zonen) was used to record time-dependent irradiance in the range $300-400 \mathrm{~nm}$ at both the horizontal direction (to evaluate the solar irradiance received by the stirred vessel reactors) and at $37^{\circ}$ angle (the same inclination as the $\mathrm{CPC}$ module) to evaluate the solar irradiance received by the $\mathrm{CPC}$. The data was collected in terms of UV irradiance $\left(\mathrm{W} / \mathrm{m}^{2}\right)$ (Figure $\left.\mathrm{S} 2\right)$. 


\subsection{Disinfection kinetics}

The inactivation kinetics of E. coli and E. faecalis followed a typical two phase behaviour and were fitted to a simple model commonly used for disinfection with AOPs as reported elsewhere [38-40]. In summary, the kinetics curve obeys to a first lag phase, also called 'shoulder', in which the concentration of viable bacteria remains stable, followed by a log-linear decay phase, which can be described by the classical Chick' Law widely used in disinfection in a wide range of bacterial inactivation processes. Table 1 shows the analysis of the experimental data with the corresponding kinetic constants in the linear phase $\left(k, \mathrm{~min}^{-1}\right)$ and shoulder length in the initial lag phase $(S L$, $\min )$.

\section{RESULTS AND DISCUSSION}

\subsection{Effect of temperature on inactivation of bacteria by PS in IW in the dark-bench} scale

The effect of temperature on the inactivation of bacteria was investigated under darkness conditions, and in the absence (control) and in the presence $(0.5 \mathrm{mM})$ of PS. The water temperature was set to $25,30,40$ and $50{ }^{\circ} \mathrm{C}$, which corresponds to the range of temperatures reached during the experiments performed under direct solar irradiation. The concentration of PS and the temperature remained constant in these $5 \mathrm{~h}$ long experiments (Figure S3). The thermal inactivation of E. coli and E. faecalis (Figure 1) at $30{ }^{\circ} \mathrm{C}, 40{ }^{\circ} \mathrm{C}$ and $50{ }^{\circ} \mathrm{C}$ followed the expected behaviour for these bacteria [14]. The thermal inactivation of both bacteria at lower temperatures between 25 and $30{ }^{\circ} \mathrm{C}$, was negligible, while it was significant at temperatures above $40{ }^{\circ} \mathrm{C}$ and markedly fast at 50 ${ }^{\circ} \mathrm{C}$. 
The results in Figure 1 and the first-order kinetic constants (Table 1) at $30^{\circ} \mathrm{C}$ show that the presence of PS $(0.5 \mathrm{mM})$ in the dark did not produce any significant bacterial inactivation for both E. coli and E. faecalis. At $40{ }^{\circ} \mathrm{C}$ the thermal inactivation of E. coli was 1.7-LRV in $5 \mathrm{~h}$, while in the presence of PS $(0.5 \mathrm{mM})$, a 3-LRV was observed in 4 h. In both cases the kinetics was first-order without lag-phase (Table 1). In constrast, $E$. faecalis shows a 3.5 -LRV at $40{ }^{\circ} \mathrm{C}$ in $4 \mathrm{~h}$, while the presence of $0.5 \mathrm{mM}$-PS at $40{ }^{\circ} \mathrm{C}$ leads to 5-LRV in 4h. Although bacterial inactivation in the presence of PS was faster, both kinetics were very similar though and with an initial lag phase of $1 \mathrm{~h}$. This clearly confirms that for temperature rising from 30 to $40{ }^{\circ} \mathrm{C}$ the presence of PS had a marked effect on E. coli (Figure 1a) and a less significant effect on E. faecalis (Figure 1b). The results at $50{ }^{\circ} \mathrm{C}$ revealed that the thermal effect at $50{ }^{\circ} \mathrm{C}$ played a dominant role, with fast bacterial decay for both bacteria, which dominates over the thermal activation of PS at such temperature.

PS has been known to be thermally activated at temperatures between 40 and $70{ }^{\circ} \mathrm{C}$ [41]. For each mole of PS, two moles of sulfate radicals are generated, therefore increasing the temperature might produce faster bacterial inactivation [42]. Nevertheless, the extremely fast thermal inactivation of E. coli and E. faecalis overshadows the impact of sulfate radicals on the bacteria and its effect can be hardly appreciated. The concentration of PS during these experiments (Figure S3) did not vary in a significant way, suggesting that there is not significant thermal dissociation of PS at any of the temperatures evaluated. Despite this, at $40{ }^{\circ} \mathrm{C}$ the results revealed an increase in the bacterial inactivation rates in the presence of PS, which may suggest that a small fraction of PS is being dissociated to produce sulfate radicals acting on the bacteria.

\section{FIGURE 1}




\subsection{Solar UVA PS activation in IW-bench scale}

The effect of different concentrations of PS $(0.00,0.01,0.05,0.1,0.2,0.5,0.7 \mathrm{mM})$ on bacteria inactivation was investigated in IW (Figure 2).

\section{FIGURE 2}

Solar UVA irradiance measured during solar tests ranged from $26.38 \pm 1.27$ to $44.44 \pm$ $1.4 \mathrm{~W} / \mathrm{m}^{2}$, corresponding to two hours of solar exposure from 10:00 AM to 12:00 PM local time. The temperature of the solar stirred tank reactors increased from $25 \pm 2{ }^{\circ} \mathrm{C}$ at the beginning of the experiment to a temperature in the range from 35 to $45{ }^{\circ} \mathrm{C}$ at the end after $2 \mathrm{~h}$. The control tests in the dark at the highest PS concentration $(0.7 \mathrm{mM})$ did not reveal any loss in the viability of both pathogens (data not shown), therefore the inactivation of bacteria can be attributed to the combined effect of PS and solar radiation. The results of PS/solar UVA showed a gradual rate of bacterial inactivation, which becomes faster at increasing PS concentrations. The time required to achieve a 6LRV of E. coli was $60 \mathrm{~min}$, in the absence of PS, while only 15 min of solar exposure was required with $0.7 \mathrm{mM}$ PS (Figure 2a). A similar behaviour of PS and solar illumination was observed for E. faecalis (Figure 2b), but it required longer exposure time periods (nearly double the times of E. coli) to reach a similar degree of logreduction. Clearly, the presence of PS enhanced the bacterial inactivation as compared with the effect of solar radiation. Similar solar disinfection results have been reported for both bacteria, in the absence of PS $[5,43]$. The bactericidal effect of sunlight is attributed to the cumulative oxidative action of UVA and UVB radiation, which acts both internally and externally of the bacteria walls [44]. The activation of PS under solar exposure is suggested to be due to the adsorption of UV radiation via the $\mathrm{O}-\mathrm{O}$ 
bond of PS, which increases in the UV region [45]. The energy required for the homolytic cleavage of PS is $140.2 \mathrm{~kJ} / \mathrm{mol}$, which is lower than the energy required to rupture other precursors of reactive oxygen species, such as $\mathrm{H}_{2} \mathrm{O}_{2}(195.4 \mathrm{~kJ} / \mathrm{mol})$ $[42,46]$. Moreover, the concentration of PS measured during experiments remained invariant in all cases (see Figure S4), thus, the PS dissociation could not be confirmed by this methodology, although the results showed faster bacterial inactivation rates at increasing PS concentrations.

The analysis of the inactivation kinetics (Table 1) of E. coli clearly shows a first-order decay beginning after a short period of latency with 'shoulder length' values varying between 10 to 15 minutes. This shoulder is commonly observed in the disinfection kinetics of other bacteria [40] and is commonly explained as the time required by the bacteria consortium to show the detrimental effects of the oxidative process.

\section{TABLE 1 (Modifications in the table)}

The time required to attain a 6-LRV of both bacteria decreased at increasing PS concentrations. The first-order kinetics rate constant of $E$. coli varied from $0.121 \pm$ 0.010 to $0.562 \pm 0.148 \mathrm{~min}^{-1}$ with maximum value at $0.5 \mathrm{mM}$ of PS, although the shoulder length varied between 5 and $15 \mathrm{~min}$ in all cases. For E. faecalis the effect of PS concentration reached a maximum for $0.7 \mathrm{mM}$ with longer SL values, between 10 and 40 minutes minutes and the first-order kinetic rate constant varied from $0.059 \pm$ 0.005 to $0.239 \pm 0.023 \mathrm{~min}^{-1}$. A higher resistance of E. faecalis as compared to E. coli against other solar AOPs has already been reported $[2,5,47]$ and this has been attributed to their different cell wall composition and outer membrane osmotic permeability. $E$. coli has a higher structural complexity but under osmotic stress, the cell wall 
deteriorates faster, that increase the permeabilityand the impact of oxidative processes [5]. In the presence of sufficient amounts of PS, the first-order inactivation rate constant increases up to 3-4 fold as compared to the results in the absence of PS. Overall, the maximum rates were achieved at $0.5 \mathrm{mM}$ PS and further increase did not show significant improvements. When observing the separate damaging effects over the bacteria of solar radiation (only) and PS (in the dark at $30{ }^{\circ} \mathrm{C}$ ), it is possible to see that the kinetic constant of the inactivation processes (Table 1) are $0.126 \pm 0.015 \mathrm{~min}^{-1}$ and

$0.000 \pm 0.004 \mathrm{~min}^{-1}$, respectively. Revealing the incapacity of PS to effectively inactivate bacteria by itself. Meanwhile the process of solar radiation with $0.5 \mathrm{mM}$-PS has an inactivation kinetic constant value equal to $(0.562 \pm 0.148) \mathrm{min}^{-1}$ for E. coli and $0.239 \pm 0.023 \mathrm{~min}^{-1}$ for E. faecalis with $0.7 \mathrm{mM}$-PS. This evidences the solar radiation may be photoactivating PS with a subsequent accelerated inactivation of E. coli and $E$. faecalis in water. These results are in agreement with previous contributions of UVAactivated persulfate for water disinfection $[26,48,49]$.

\subsection{Solar UVA and thermal PS activation in IW-pilot scale}

The dual activation of PS by solar radiation and solar thermal heating and the inactivation of E. coli and E. faecalis in IW was further investigated in a 60 L-CPC pilot scale reactor using $0.5 \mathrm{mM}$ of PS. The thermal factor was considered under three tests, one exposed to the natural solar heating occurring in the $\mathrm{CPC}$ reactor during the experiments, this is from $30{ }^{\circ} \mathrm{C}$ at the start of the experiment, increasing up to $39^{\circ} \mathrm{C}$ in 1 $\mathrm{h}, 43{ }^{\circ} \mathrm{C}$ in $2 \mathrm{~h}$, and $46^{\circ} \mathrm{C}$ in $3 \mathrm{~h}$ (end of the experiment), and two other at constant temperatures, $30{ }^{\circ} \mathrm{C}$ and $50{ }^{\circ} \mathrm{C}$, achieved by a thermal control system installed in the reactor. Two additional control runs were performed: i) a solar photo-inactivation experiment to determine the effect of solar UV and solar heating effects on the bacterial 
survival; and ii) a dark control in the reactor with $0.5 \mathrm{mM}$ PS under solar heating, to determine the thermal activation effect of PS under solar mild temperatures $\left(50^{\circ} \mathrm{C}\right)$.

Solar UVA radiation averaged among the entire solar tests performed at pilot scale ranged from $23.29 \pm 12.27$ to $44.60 \pm 1.21 \mathrm{~W} / \mathrm{m}^{2}$, starting at $10: 15$ am local time and lasting $2.5 \mathrm{~h}$ of solar exposure.

The results show that dark thermal PS activation occurs after 1 hour (Figure 3), which explains the fast first-order inactivation kinetics observed thereafter. For both bacteria the inactivation profiles followed similar trends.

\section{FIGURE 3}

The photo-thermal activation of PS at solar mild temperatures clearly shows inactivation results that fit in between the solar activated at $30{ }^{\circ} \mathrm{C}$ and $50{ }^{\circ} \mathrm{C}$, which is to be expected given the thermal pattern observed in the $\mathrm{CPC}$ reactor. This highlights the concerted effect of solar UV and solar thermal heating in enhancing the water disinfection at pilot scale using PS. PS activation both through solar UVA and solar thermal in the CPC reactor contributed to enhance system efficiency, when compared to the solar UVA and solar thermal separately, thus reducing inactivation time in about 30 minutes. Supposedly, when gathering the two activators, more peroxide bonds can be disrupted and consequently the generation of sulfate radicals will be higher [45]. It is expected that the synergistic effect would be a sum of both energies received by PS, translating into a more promptly inactivation.

The impact of temperature on solar AOPs has been previous investigated. High

temperatures have been reported to increase the intracellular $\mathrm{pH}$, membrane potential and its permeability and also the generation of reactive oxygen species leading to cell 
injury $[43,50]$. Recently the synergistic effect of solar mild heat and solar UVA has been reported and mathematically modeled in solar reactors, under the well-known process SODIS (solar water disinfection) [51]. $\mathrm{TiO}_{2}$ heterogeneous photocatalysis applied to the inactivation of E. coli and F. solani in water at pilot scale has also been reported to proceed at faster rates at higher water temperatures (from $15{ }^{\circ} \mathrm{C}$ to $45^{\circ} \mathrm{C}$ ) [36]. Similarly, beneficial effects of solar mild temperatures have been reported using solar photo-Fenton for the inactivation of E. faecalis [52]. Marjanovic and collaborators (2018) reported an enhancement in the reaction inactivation rates when the solar and thermal effects were combined to activate PS. For PS solar activation, the quantum yield is less than $1\left(25^{\circ} \mathrm{C}\right)$. Moreover, adding the thermal effect, a lower amount of solar energy was necessary to activate PS [25].

\subsection{PS activation in SUWW- bench scale}

\subsubsection{Persulfate + sunlight}

The influence of organic matter during bacterial inactivation by solar and thermal activation of PS was also investigated. Figure $4(a, b)$ shows the inactivation kinetics of E. coli and E. faecalis in SUWW under solar radiation with concentrations of PS ranged from 0.2 to $1 \mathrm{mM}$. As observed for IW, the addition of PS accelerates the inactivation of both bacteria in comparison with solar disinfection alone. In this case, the concentration of PS that led to the highest inactivation kinetic rate (Table 1) was $1 \mathrm{mM}$ for E. coli and $0.7 \mathrm{mM}$ for E. faecalis, which is in agreement with the obtained data in IW (Figure 2) for E. faecalis. Additionally, similar results regarding the observed kinetics shape and level of resistance of each bacterium were found. E. coli was more sensitive to the treatment than E. faecalis. Nevertheless, significant lower inactivation rate constants were obtained in SUWW compared to IW. Taking into consideration the highest 
inactivation rates for both in SUWW and IW, the $k$ values were 5.1-fold lower for $E$. coli and 2.5-fold lower for E. faecalis in SUWW compared to IW (Table 1).

\section{FIGURE 4}

As aforementioned, PS concentration is stable and can be activated in solution at several $\mathrm{pH}$, but the $\mathrm{SO}_{4}{ }^{--}$generation rate is dependent on the $\mathrm{pH}$ value $[31,53,54]$. In this study the working $\mathrm{pH}$ of the SUWW was $8.15 \pm 0.30$ and the measurements of dissolved organic carbon (DOC) during the process did not show significant degradation (data not shown). Additionally, the concentration of PS remained constant (Figure S2). The presence of DOC $(25 \pm 5 \mathrm{mg} / \mathrm{L})$ slowed the bacterial inactivation process . The possible reactions occurring between $\mathrm{SO}_{4}{ }^{--}$and $\mathrm{DOC}$ may be another reason for not achieving sufficiently high disinfection levels, once it seems that there are not being generated enough radicals at this $\mathrm{pH}$, in comparison with the case of IW (at $\mathrm{pH} 5.5 \pm 0.25$ ). In fact, the $\mathrm{pH}$ is an additional factor affecting the inactivation efficiency, because at $\mathrm{pH}<$ 7 less sulfate radicals are produced. Several authors analysed the formation rate of sulfate radicals and hydroxyl radicals under different $\mathrm{pH}$ and concluded that below $\mathrm{pH} 7$ $\mathrm{SO}_{4}{ }^{--}$is the most prevalent oxidative species, while at $\mathrm{pH}=9, \mathrm{SO}_{4}{ }^{--}$and hydroxyl radicals are generated at equal rates. However, at $\mathrm{pH}>9$ the prevailing radical species are hydroxyl radicals $[31,54]$. It is also known that the reaction of DOC with $\mathrm{SO}_{4}^{{ }^{-}}$ proceed at lower rates $\left(6.8 \times 10^{3} \mathrm{mg} / \mathrm{Cs}\right)$ compared to the reaction with the hydroxyl radical $\left(1.4 \times 10^{4} \mathrm{mg} / \mathrm{Cs}\right)$ [55], due to the hydrogen-abstraction reactions being slower with $\mathrm{SO}_{4}^{{ }^{--}}$[53]. In addition, $\mathrm{SO}_{4}{ }^{--}$may react with several common anionic species present in water, including $\mathrm{HCO}_{3}{ }^{-}, \mathrm{HPO}_{4}{ }^{2-}, \mathrm{Cl}^{-}$and $\mathrm{CO}_{3}{ }^{2-}$ ending in weaker radicals [55], or even quench them [54], which corroborates with the lower inactivation kinetics 
rates obtained with SUWW, in comparison to IW. Furthermore, the scavenging effect of $\mathrm{Cl}^{-}$can act in two ways: it can compromise UV PS activation, or can form chlorine or dichlorine radicals which are able to react more selectively [56] and this can increase the efficiency in some cases. Therefore, in the presence of DOC $=25 \mathrm{mg} / \mathrm{L}, \mathrm{pH}$ changes did not drive the sulfate radicals generation process via activation of PS.

\subsubsection{Persulfate + temperature (dark)}

The thermal activation of PS in the presence of organic matter was also investigated. Figure 5 shows the inactivation of E. coli and E. faecalis at several temperatures under darkness $\left(30,40\right.$ and $\left.50{ }^{\circ} \mathrm{C}\right)$ with and without $0.5 \mathrm{mM}$ of PS.

\section{FIGURE 5}

The inactivation trend obtained revealed that temperatures lower than $40{ }^{\circ} \mathrm{C}$ do not show any significant detrimental effect on bacterial viability, both with and without PS. Only at $50{ }^{\circ} \mathrm{C}$ the detection limit was reached within $80 \mathrm{~min}$ in presence of PS compared with the absence of PS (100 min), for both bacteria, demonstrating the thermal activation of PS by mild-heat temperatures, in this case $50{ }^{\circ} \mathrm{C}$. The higher energy was able to disrupt the peroxide bond, in order to generate the sulfate radicals. The prompt conversion of sulfate radicals into hydroxyl radicals, make these last radicals the major contributor for the process [54]. On the other hand, lower inactivation kinetics rates were again obtained in SUWW compared to IW due to the presence of DOC.

\section{CONCLUSIONS}


In this study, the activation of persulfate by solar radiation and mild heat was demonstrated to accelerate the rate of water disinfection in both IW and SUWW matrices.

Thermal activation of PS at $50{ }^{\circ} \mathrm{C}$ led to more effective bacterial inactivation than at 40 ${ }^{\circ} \mathrm{C}$ with $0.5 \mathrm{mM}$ of PS, highlighting the impact of temperature alone on the rate of inactivation. E. coli revealed to be a more resistant bacteria to thermal inactivatation than E. faecalis.

The efficiency of solar PS for the inactivation of E. coli and E. faecalis in IW was proven. The highest inactivation rate constants for both bacteria were obtained for 0.5 and $0.7 \mathrm{mM}$ of persulfate, requiring only 20 minutes of solar exposure to achieve the detection limit for E. coli and E. faecalis, respectively.

The scaling-up of process using a pilot solar reactor of $60 \mathrm{~L}$ of treatment capacity has been successfully proven for $0.5 \mathrm{mM}$ of PS with solar radiation. In brief, faster inactivation rates for E. coli than for E. faecalis, and overall enhanced results when using $0.5 \mathrm{mM}$ of PS with solar (optical and thermal).

Regarding the disinfection of SUWW, where the presence of organic matter becomes an added complexity for disinfection, 1 and $0.7 \mathrm{mM}$ of PS were found to be the most effective concentrations for the inactivation of E. coli and E. faecalis, respectively via solar (optical and thermal) with PS, showing similar inactivation kinetics trend as in IW. Finally, the proposed method demonstrates promising results for the disinfection of wastewater. 6-log reduction of bacteria concentration was achieved using low amounts of PS $(0.5 \mathrm{mM})$ and solar radiation periods of less than 2 hours. Further solar treatment studies should be performed using actual urban wastewater effluents at large scale. Additionally, it is necessary to find a methodology capable of measuring PS anions or sulfate radicals generated from UVA solar and thermal activation mechanisms. 
Nevertheless, the present work showed very promising results in terms of water disinfection.

\section{CONFLICTS OF INTEREST}

There are no conflicts to declare.

\section{ACKNOWLEDGEMENTS}

The authors acknowledge the financial support provided by SFERA - Solar Facilities for the European Research Area (228296) and by the FCT-Portuguese Foundation for Science and Technology (PD/BD/128270/2017), under the Doctoral Programme "Agricultural Production Chains - from fork to farm" (PD/00122/2012) and the CQVR through PEst-C/QUI/UI0616/2014. Marco S. Lucas also acknowledges the funding provided by the European Union's Horizon 2020 research and innovation programme under the Marie Sklodowska-Curie grant agreement No 660969.

\section{REFERENCES}

[1] C. Han, J. Lalley, D. Namboodiri, K. Cromer, M.N. Nadagouda, Titanium dioxidebased antibacterial surfaces for water treatment, Curr. Opin. Chem. Eng. 11 (2016) 4651. https://doi.org/10.1016/j.coche.2015.11.007.

[2] A.Y. Booshehri, M.I. Polo-Lopez, M. Castro-Alférez, P. He, R. Xu, W. Rong, S. Malato, P. Fernández-Ibáñez, Assessment of solar photocatalysis using $\mathrm{Ag} / \mathrm{BiVO}_{4}$ at pilot solar Compound Parabolic Collector for inactivation of pathogens in well water $\begin{array}{llllll}\text { and secondary effluents, } & \text { Catal. Today } 281 & \text { (2017) } & \text { 124-134. }\end{array}$ https://doi.org/10.1016/j.cattod.2016.08.016.

[3] K.L. Kotloff , J.P. Nataro, W.C. Blackwelder, D. Nasrin, T.H. Farag, S. Panchalingam, Y. Wu, S.O. Sow, D. Sur, R.F. Breiman, A.S.G. Faruque, A.K.M. Zaidi, 
D. Saha, P.L. Alonso, B. Tamboura, D. Sanogo, U. Onwuchekwa, B. Manna, T. Ramamurthy, S. Kanungo, J.B. Ochieng, R. Omore, J.O. Oundo, A. Hossain, S.K. Das, S. Ahmed, S. Qureshi, F. Quadri, R.A. Adegbola, M. Antonio, M.J. Hossain, A. Akinsola, I. Mandomando, T. Nhampossa, S. Acácio, K. Biswas, C.E. O’Reilly, E.D. Mintz, L.Y. Berkeley, K. Muhsen, H. Sommerfelt, R.M. Robins-Browne, M.M. Levine, Burden and aetiology of diarrhoeal disease in infants and young children in developing countries (the Global Enteric Multicenter Study, GEMS): a prospective, case-control study, The Lancet, 382 (2013) 209-222.

[4] A. Flammini, M. Puri, L. Pluschke, O. Dubois, Walking the nexus talk: Assessing the Water-Energy-Food Nexus in the Context of the Sustainable Energy for All Initiative, Environment and Natural Resources Working Paper No. 58, FAO, Rome, 2014.

[5] J. Rodríguez-Chueca, M.I. Polo-López, R. Mosteo, M.P. Ormad, P. FernándezIbáñez, Disinfection of real and simulated urban wastewater effluents using a mild solar photo-Fenton, Appl. Catal. B: Environ. 150-151 (2014) 619-629. https://doi.org/10.1016/j.apcatb.2013.12.027.

[6] A. Bianco, M.I. Polo-López, P. Fernández-Ibáñez, M. Brigante, G. Mailhot, Disinfection of water inoculated with Enterococcus faecalis using solar/Fe(III)EDDS$\mathrm{H}_{2} \mathrm{O}_{2}$ or $\mathrm{S}_{2} \mathrm{O}_{8}{ }^{2-} \quad$ process, Water Res. $118 \quad$ (2017) 249-260. https://doi.org/10.1016/j.watres.2017.03.061.

[7] S. Bounty, R.A. Rodriguez, K.G. Linden, Inactivation of adenovirus using low-dose $\mathrm{UV} / \mathrm{H}_{2} \mathrm{O}_{2}$ advanced oxidation, Water Res. $46 \quad$ (2012) 6273-6278. https://doi.org/10.1016/j.watres.2012.08.036. 
[8] M. Cho, H. Chung, W. Choi, J. Yoon, Linear correlation between inactivation of $E$. coli and $\mathrm{OH}$ radical concentration in $\mathrm{TiO}_{2}$ photocatalytic disinfection, Water Res. 38 (2004) 1069-1077. https://doi.org/10.1016/j.watres.2003.10.029.

[9] M. Cho, J.-H. Kim, J. Yoon, Investigating synergism during sequential inactivation of Bacillus subtilis spores with several disinfectants, Water Res. 40 (2006) 2911-2920. https://doi.org/10.1016/j.watres.2006.05.042.

[10] A. Ruiz-Aguirre, M.I. Polo-López, P. Fernández-Ibáñez, G. Zaragoza, Integration of Membrane Distillation with solar photo-Fenton for purification of water contaminated with Bacillus sp. and Clostridium sp. spores, Sci. Total Environ. 595 (2017) 110-118. https://doi.org/10.1016/j.scitotenv.2017.03.238.

[11] W. Yu, Q. Wen, J. Yang, K. Xiao, Y. Zhu, S. Tao, Y. Lv, S. Liang, W. Fan, S. Zhu, B. Liu, H. Hou, J. Hu, Unraveling oxidation behaviors for intracellular and extracellular from different oxidants $\left(\mathrm{HOCl} v s . \mathrm{H}_{2} \mathrm{O}_{2}\right)$ catalyzed by ferrous iron in waste activated sludge dewatering. Water Res. $148 \quad$ (2019) 60-69. https://www.ncbi.nlm.nih.gov/pubmed/30347276.

[12] Y. Shi, J. Yang, W. Yu, S. Zhang, S. Liang, J. Song, Q. Xu, N. Ye, S. He, C. Yang, J. $\mathrm{Hu}$, Synergetic conditioning of sewage sludge via $\mathrm{Fe}^{2+} /$ persulfate and skeleton builder: Effect on sludge characteristics and dewaterability, Chem. Eng. J. 270 (2015) 572-581. https://www.sciencedirect.com/science/article/pii/S138589471500159X.

[13] A. Fiorentino, G. Ferro, M.C. Alferez, M.I. Polo-López, P. Fernández-Ibañez, L. Rizzo, Inactivation and regrowth of multidrug resistant bacteria in urban wastewater after disinfection by solar-driven and chlorination processes, J. Photochemist. Photobiol. B: $\quad$ Biology 148 $43-50$. https://doi.org/10.1016/j.jphotobiol.2015.03.029. 
[14] M. Castro-Alférez, M.I. Polo-López, J. Marugán, P. Fernández-Ibáñez, Mechanistic modeling of UV and mild-heat synergistic effect on solar water disinfection, Chem. $\quad$ Eng. J. $316 \quad$ (2017) https://doi.org/10.1016/j.cej.2017.01.026.

[15] A.G. Gutierrez-Mata, S. Velazquez-Martínez, A. Álvarez-Gallegos, M. Ahmadi, J. A. Hernández-Pérez, F. Ghanbari, S. Silva-Martínez, Recent Overview of Solar Photocatalysis and Solar Photo-Fenton Processes for Wastewater Treatment - Review Article, Int. J. Photoenergy 8528063, (2017) 1-27. https://doi.org/10.1155/2017/8528063.

[16] P. Sun, C. Tyree, C.-H. Huang, Inactivation of E. coli, Bacteriophage MS2 and Bacillus Spores under $\mathrm{UV} / \mathrm{H}_{2} \mathrm{O}_{2}$ and UV/Peroxydisulfate Advanced Disinfection Conditions, Environ, Sci. Technol. $50 \quad$ (2016) 4448-4458. https://pubs.acs.org/doi/10.1021/acs.est.5b06097.

[17] J. Rodríguez-Chueca, T. Silva, J.R. Fernandes, M.S. Lucas, G. Li Puma, J.A. Peres, A. Sampaio, Inactivation of pathogenic microorganisms in freshwater using $\mathrm{HSO}_{5}{ }^{-} / \mathrm{UV}-$ A LED and $\mathrm{HSO}_{5}{ }^{-} / \mathrm{M}^{\mathrm{n}+} / \mathrm{UV}-\mathrm{A}$ LED oxidation processes, Water Res. 123 (2017) 113123. https://doi.org/10.1016/j.watres.2017.06.021.

[18] J. Moreno-Andrés, R. R. Quintero, A. Acevedo-Merino, E. Nebot, Disinfection performance using a UV/persulfate system: effects derived from different aqueous $\begin{array}{llllll}\text { matrices, } & \text { Photochem. } & \text { Photobiol. } & \text { Sci. } & 18 & \text { (2019) }\end{array}$ https://pubs.rsc.org/en/content/articlelanding/2019/pp/c8pp00304a.

[19] L. Chen, M. Tang, C. Chen, M. Chen, K. Luo, J. Xu, D. Zhou, F. Wu, Efficient Bacterial Inactivation by Transition Metal Catalyzed Auto-Oxidation of Sulfite, $\begin{array}{llllll}\text { Environ. } & \text { Sci. } & \text { Technol. } & 51, \quad 2017) & \text { 12663-12671. }\end{array}$ https://pubs.acs.org/doi/abs/10.1021/acs.est.7b03705. 
[20] R.H. Waldemer, P.G. Tratnyek, R.L. Johnson, J.T. Nurmi, Oxidation of Chlorinated Ethenes by Heat-Activated Persulfate: Kinetics and Products, Environ. Sci. Technol. 41 (2007) 1010-1015. https://pubs.acs.org/doi/abs/10.1021/es062237m.

[21] M. Ahmadi, J. Behin, A.R. Mahnam, Kinetics and thermodynamics of peroxydisulfate oxidation of Reactive Yellow 84, J. Saudi Chem. Soc. 20 (2016) 644650. https://doi.org/10.1016/j.jscs.2013.07.004.

[22] N. Garkusheva, G. Matafonova, I. Tsenter, S. Beck, V. Batoev, K. Linden, Simultaneous atrazine degradation and E. coli inactivation by simulated solar photoFenton-like process using persulfate, J. Environ. Sci. Health, Part A 52 (2017) 849-855. https://doi.org/10.1080/10934529.2017.1312188.

[23] Y. Ji, L. Wang, M. Jiang, J. Lu, C. Ferronato, J.M. Chovelon, The role of nitrite in sulfate radical-based degradation of phenolic compounds: An unexpected nitration process relevant to groundwater remediation by in-situ chemical oxidation (ISCO), Water Res. 123 (2017) 249-257. https://doi.org/10.1016/j.watres.2017.06.081.

[24] L. Lian, B. Yao, S. Hou, J. Fang, S. Yan, W. Song, Kinetic Study of Hydroxyl and Sulfate Radical-Mediated Oxidation of Pharmaceuticals in Wastewater effluents, $\begin{array}{llllll}\text { Environ. } & \text { Sci. } & \text { Technol. } & 51 & \text { (2017) }\end{array}$ https://pubs.acs.org/doi/abs/10.1021/acs.est.6b05536.

[25] M. Marjanovic, S. Giannakis, D. Grandjean, L.F. de Alencastro, C. Pulgarin, Effect of $\mu \mathrm{M}$ Fe addition, mild heat and solar UV on sulfate radical-mediated inactivation of bacteria, viruses, and micropollutant degradation in water, Water Res. 140 (2018) 220231. https://doi.org/10.1016/j.watres.2018.04.054.

[26] M.G. Antoniou, A.A. de la Cruz, D.D. Dionysiou, Degradation of microcystin-LR using sulfate radicals generated through photolysis, thermolysis and $\mathrm{e}^{-}$transfer 
mechanisms, Appl. Catal. B: Environ. $96 \quad$ (2010) 290-298. https://doi.org/10.1016/j.apcatb.2010.02.013.

[27] C. Liang, Z.-S. Wang, N. Mohanty, Influences of carbonate and chloride ions on persulfate oxidation of trichloroethylene at $20{ }^{\circ} \mathrm{C}$, Sci. Total Environ. 370 (2006) 271277. https://doi.org/10.1016/j.scitotenv.2006.08.028.

[28] Y.-F. Huang, Y.-H. Huang, Identification of produced powerful radicals involved in the mineralization of bisphenol $\mathrm{A}$ using a novel UV- $\mathrm{Na}_{2} \mathrm{~S}_{2} \mathrm{O}_{8} / \mathrm{H}_{2} \mathrm{O}_{2}-\mathrm{Fe}$ (II, III) twostage oxidation process, J. Hazard. Mat. $162 \quad$ (2009) 1211-1216. https://doi.org/10.1016/j.jhazmat.2008.06.008.

[29] N. Potakis, Z. Frontistis, M. Antonopoulou, I. Konstantinou, D. Mantzavinos, Oxidation of bisphenol A in water by heat-activated persulfate, J. Environ. Manag. 195(2) (2017) 125-132. https://doi.org/10.1016/j.jenvman.2016.05.045.

[30] Y.-T. Lin, C. Liang, J.-H. Chen, Feasibility study of ultraviolet activated persulfate oxidation of phenol, Chemosphere $82 \quad$ (2011) 1168-1172. https://doi.org/10.1016/j.chemosphere.2010.12.027.

[31] R. Hazime, Q.H.Nguyen, C. Ferronato, A. Salvador, F. Jaber, J.-M. Chovelon, Comparative study of imazalil degradation in three systems: $\mathrm{UV} / \mathrm{TiO}_{2}, \mathrm{UV} / \mathrm{K}_{2} \mathrm{~S}_{2} \mathrm{O}_{8}$ and $\mathrm{UV} / \mathrm{TiO}_{2} / \quad \mathrm{K}_{2} \mathrm{~S}_{2} \mathrm{O}_{8}$, Appl. $\quad$ Catal. $\quad$ B: $\quad$ Environ. $144 \quad$ (2014) 286-291. https://doi.org/10.1016/j.apcatb.2013.07.001.

[32] H. Hermann, On the photolysis of simple anions and neutral molecules as sources of $\mathrm{O}-/ \mathrm{OH}, \mathrm{SOx}-$ and $\mathrm{Cl}$ in aqueous solution, Phys. Chem. Chem. Phys. 9 (2007) 39254032. 10.1039/B618565G.

[33] I. Michael-Kordatou, M. Iacovou, Z. Frontistis, E. Hapeshi, D.D. Dionysiou, D. Fatta-Kassinos, Erythromycin oxidation and ERY-resistant Escherichia coli inactivation 
in urban wastewater by sulfate radical-based oxidation process under UV-C irradiation, Water Res. 85 (2015) 346-358. https://doi.org/10.1016/j.watres.2015.08.050.

[34] D. Xia, H. He, H. Liu, Y. Wang, Q. Zhang, Y. Li, A. Lu, C. He, P.K. Wong, Persulfate-mediated catalytic and photocatalytic bacterial inactivation by magnetic natural ilmenite, Appl. Catal. B: Environ. $238 \quad$ (2018) 70-81. https://doi.org/10.1016/j.apcatb.2018.07.003.

[35] R. Xiao, K. Liu, L. Bai, D. Minakata, Y. Seo, R.K. Göktaş, D.D. Dionysiou, C.-J. Tang, Z.Wei, R. Spinney, Inactivation of pathogenic microorganisms by sulfate radical: Present and future - Review, Chem. Eng. J. 371 (2019) 222-232. https://doi.org/10.1016/j.cej.2019.03.296.

[36] C. Liang, C-F. Huang, N. Mohanty, R.M. Kurakalva, A rapid spectrophotometric determination of persulfate anion in ISCO, Chemosphere 73 (2008) 1540-1543. https://doi.org/10.1016/j.chemosphere.2008.08.043.

[37] M.I. Polo-López, I. García-Fernández, I. Oller, P. Fernández-Ibáñez, Solar disinfection of fungal spores in water aided by low concentrations of hydrogen $\begin{array}{llllll}\text { peroxide, } & \text { Photochem. } & \text { Photobiol. } & \text { Sci. } & 10 & \text { (2011) }\end{array}$ https://www.ncbi.nlm.nih.gov/pubmed/20859602.

[38] I. García-Fernández, I. Fernández-Calderero, M.I. Polo-López, P. FernándezIbáñez, Disinfection of urban effluents using solar $\mathrm{TiO}_{2}$ photocatalysis: A study of significance of dissolved oxygen, temperature, type of microorganism and water matrix, Catal. Today 240 (2015) 30-38. https://doi.org/10.1016/j.cattod.2014.03.026.

[39] G. Ferro, A. Fiorentino, M.C. Alferez, M.I. Polo-López, L. Rizzo, P. FernándezIbáñez, Urban wastewater disinfection for agricultural reuse: effect of solar driven AOPs in the inactivation of a multidrug resistant E. coli strain, Appl. Catal. B:Environ. 178 (2015) 65-73. https://doi.org/10.1016/j.apcatb.2014.10.043. 
[40] M.I. Polo-López, I. García-Fernández, T. Velegraki, A. Katsoni, I. Oller, D. Mantzavinos, P. Fernández-Ibáñez, Mild solar photo-Fenton: An effective tool for the removal of Fusarium from simulated municipal effluents, Appl. Catal. B: Environ. 111112 (2012) 545- 554. https://doi.org/10.1016/j.apcatb.2011.11.006.

[41] G.P. Anipsitakis, D.D. Dionysiou, Degradation of Organic Contaminants in Water with Sulfate Radicals Generated by the Conjunction of Peroxymonosulfate with Cobalt, $\begin{array}{llllll}\text { Environ. } & \text { Sci. } & \text { Technol. } & 37 & \text { (2003) } & \text { 4790-4797. }\end{array}$ https://pubs.acs.org/doi/abs/10.1021/es0263792.

[42] I.A. Ike, K. Linden, J. Orbell, M. Duke, Critical review of the science and sustainability of persulphate advanced oxidation processes, Chem. Eng. J. 338 (2018) 651-669. https://doi.org/10.1016/j.cej.2018.01.034.

[43] M. Castro-Alférez, M.I. Polo-López, J. Marugán, P. Fernández-Ibáñez, Mechanistic model of the Escherichia coli inactivation by solar disinfection based on the photo-generation of internal ROS and the photo-inactivation of enzymes: CAT and SOD, Chem. Eng. J. 318 (2017) 214-223. https://doi.org/10.1016/j.cej.2016.06.093.

[44] M. Castro-Alférez, M.I. Polo-López, P. Fernández-Ibáñez, Intracellular mechanisms of solar water disinfection, Sci. Rep. 6 (2016) 38145. https://doi.org/10.1038/srep38145.

[45] M. Khandarkhaeva, A. Batoeva, D. Aseev, M. Sizykh, O. Tsydenova, Oxidation of atrazine in aqueous media by solar- enhanced Fenton-like process involving persulfate and ferrous ion, Ecotoxicol. Environ. Saf. $137 \quad$ (2017) 35-41. https://doi.org/10.1016/j.ecoenv.2016.11.013.

[46] S. Wacławek, H.V. Lutze, K. Grübel, V.V.T. Padil, M. Černík, D.D. Dionysiou, Chemistry of persulfates in water and wastewater treatment: A review, Chem. Eng. J. 330 (2017) 44-62. https://doi.org/10.1016/j.cej.2017.07.132. 
[47] R. van Grieken, J. Marugán, C. Pablos, L. Furones, A. López, Comparison between the photocatalytic inactivation of Gram-positive E. faecalis and Gram-negative E. coli faecal contamination indicator microorganisms, Appl. Catal. B: Environ. 100 (2010) 212-220. https://doi.org/10.1016/j.apcatb.2010.07.034.

[48] J.A. Khan, X. He, N.S. Shah, H.M. Khan, E. Hapeshi, D. Fatta-Kassinos, D.D. Dionysiou, Kinetic and Mechanism Investigation on the Photochemical Degradation of Atrazine with Activated $\mathrm{H}_{2} \mathrm{O}_{2}, \mathrm{~S}_{2} \mathrm{O}_{8}{ }^{2-}$ and $\mathrm{HSO}_{5}^{-}$, Chem. Eng. J. 252 (2014) 393-403. https://doi.org/10.1016/j.cej.2014.04.104.

[49] J. Rodríguez-Chueca, C. Amor, T. Silva, D.D. Dionysiou, G. Li Puma, M.S. Lucas, J.A. Peres, Treatment of winery wastewater by sulphate radicals: $\mathrm{HSO}_{5}{ }^{-/}$transition metal/UV-A LEDs, Chem. Eng. J. $310 \quad$ (2017) 473-483. https://doi.org/10.1016/j.cej.2016.04.135.

[50] S. Baatout, P. de Boever, M. Mergeay, Temperature-induced changes in bacterial physiology as determined by flow cytometry, Ann. Microbiol. 55 (2005) 73-80.

[51] M. Castro-Alférez, M.I. Polo-López, J. Marugán, P. Fernández-Ibáñez, Validation of a solar-thermal water disinfection model for Escherichia coli inactivation in pilot scale solar reactors and real conditions, Chem. Eng. J. 331 (2018) 831-840. https://doi.org/10.1016/j.cej.2017.09.015.

[52] E. Ortega-Gómez, P. Fernández-Ibáñez, M.M.B. Martín, M.I. Polo-López, B.E. García, J.A.S. Pérez, Water disinfection using photo-Fenton: Effect of temperature on Enterococcus faecalis survival, Water Res. $46 \quad$ (2012) 6154-6162. https://doi.org/10.1016/j.watres.2012.09.007.

[53] N.K.V. Leitner, Sulfate radical ion - based AOPs in: M.I. Stefan, Advanced Oxidation Processes for Water Treatment: Fundamentals and Applications, IWA Publishing, London, 2018, pp. 429-455. 
[54] J. Wang, S. Wang, Activation of persulfate (PS) and peroxymonosulfate (PMS) and application for the degradation of emerging contaminants - Review, Chem. Eng. J. 334 (2018) 1502-1517. https://doi.org/10.1016/j.cej.2017.11.059.

[55] W.-D. Oh, Z. Dong, T.-T. Lim, Generation of sulfate radical through heterogeneous catalysis for organic contaminants removal: Current development, challenges and prospects, Appl. Catal. B: Environ. 194 (2016) 169-201. https://doi.org/10.1016/j.apcatb.2016.04.003.

[56] W. Huang, A. Bianco, M. Brigante, G. Mailhot, UVA-UVB activation of hydrogen peroxide and persulfate for Advanced Oxidation Processes: Efficiency, mechanism and effect of various water constituents, J. Hazard. Mater. 347 (2018) 279-287. https://doi.org/10.1016/j.jhazmat.2018.01.006.

\section{Figure Captions}

Figure 1. Influence of temperature on E. coli (a) and E. faecalis (b) inactivation and PS activation in IW in the dark. $0.5 \mathrm{mM}$ of PS, bench scale reactor.

Figure 2. Inactivation of E. coli (a) and E. faecalis (b) in IW with several concentrations of PS under natural sunlight: $0.01,0.05,0.1,0.2,0.5,0.7 \mathrm{mM}$ and solar only disinfection, bench scale reactor.

Figure 3. Influence of temperature and solar radiation on E. coli (a) and E. faecalis (b) inactivation with $0.5 \mathrm{mM}$ of PS in a solar CPC reactor in IW, at pilot scale $(60 \mathrm{~L})$.

Figure 4. Inactivation of E. coli (a) and E. faecalis (b) in SUWW with several concentrations of PS under natural sunlight: $0.2,0.5,0.7$ and $1 \mathrm{mM}$ and solar only disinfection, at bench scale. 
Figure 5. Influence of temperature on E. coli (a) and E. faecalis (b) inactivation and PS activation in the dark with $0.5 \mathrm{mM}$ of PS in SUWW, at bench scale.

\section{Table Caption}

Table 1. The kinetic model used in each case has been selected based on the higher root mean square obtained for different models. 

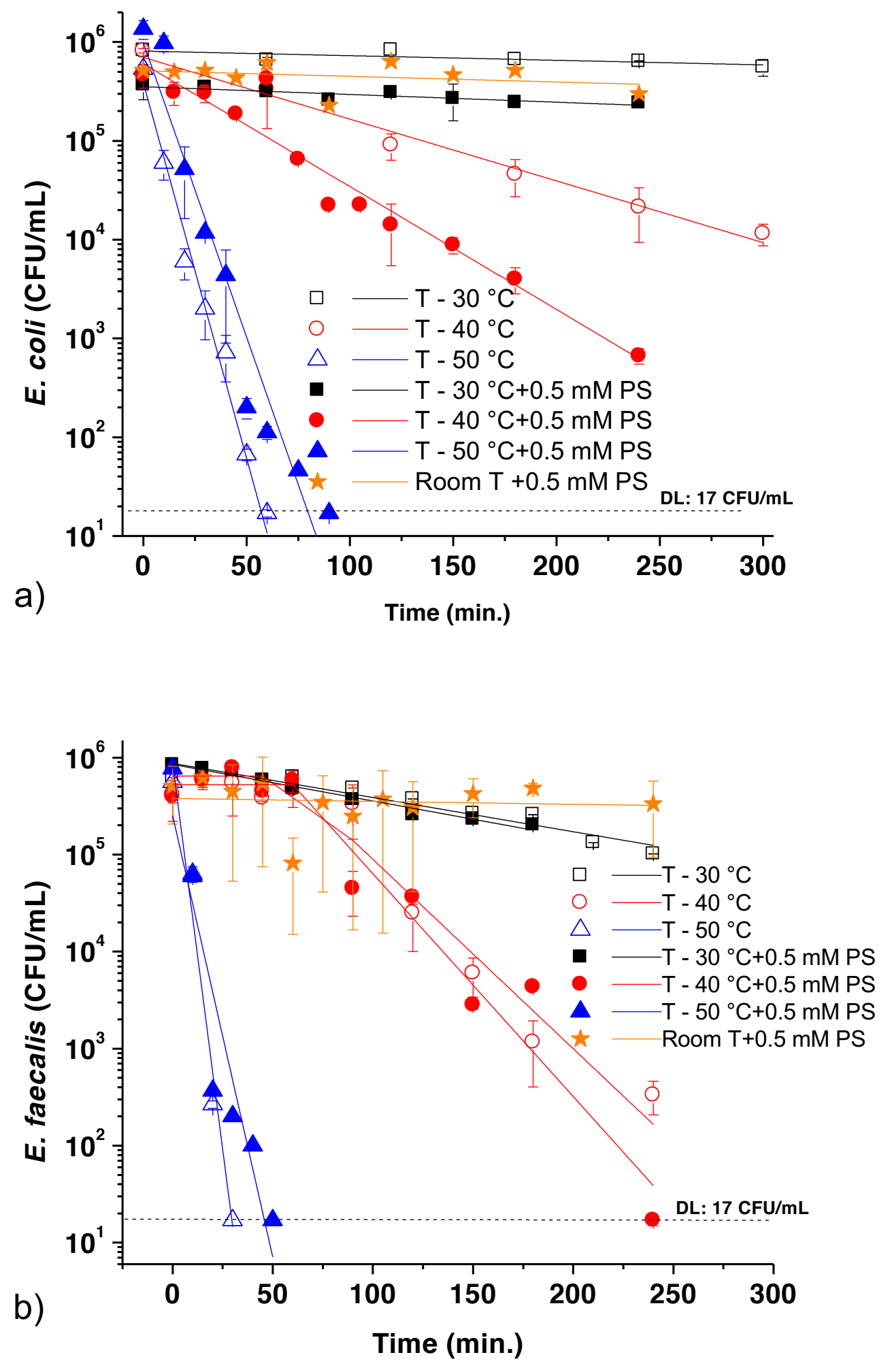
Figure 1: Influence of temperature on E. coli (a) and E. faecalis (b) inactivation and PS activation in the dark. $0.5 \mathrm{mM}$ of PS, bench scale reactor. 

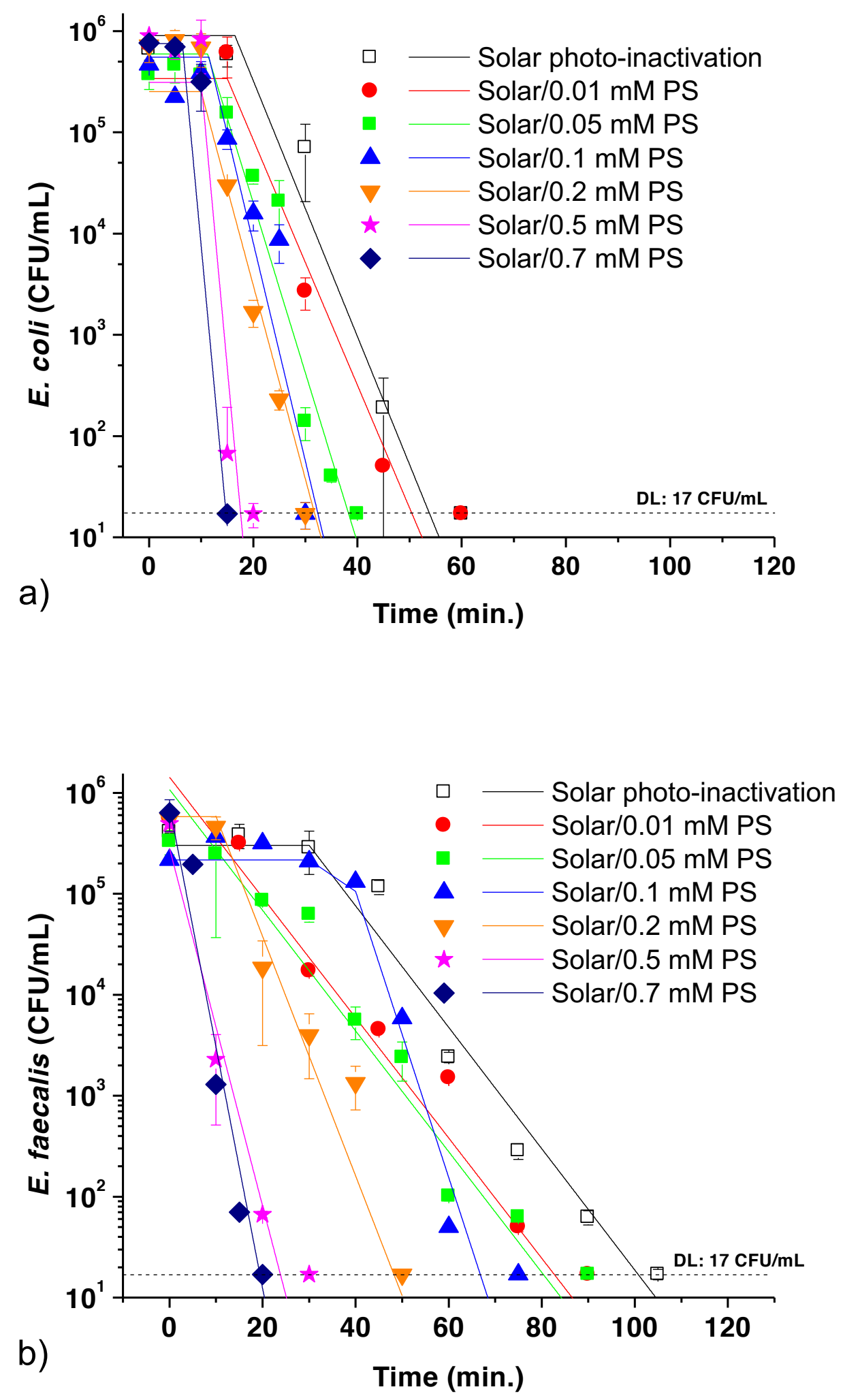

Figure 2. Inactivation of E. coli (a) and E. faecalis (b) in IW within several concentrations of PS under natural sunlight: $0.01,0.05,0.1,0.2,0.5,0.7 \mathrm{mM}$ and solar only disinfection, bench scale reactor $\left(\mathrm{T}_{0 \mathrm{~min}}=\right.$ $25 \pm 2{ }^{\circ} \mathrm{C}$ and $\left.\mathrm{T}_{120 \min }=35-45^{\circ} \mathrm{C}\right)$. 

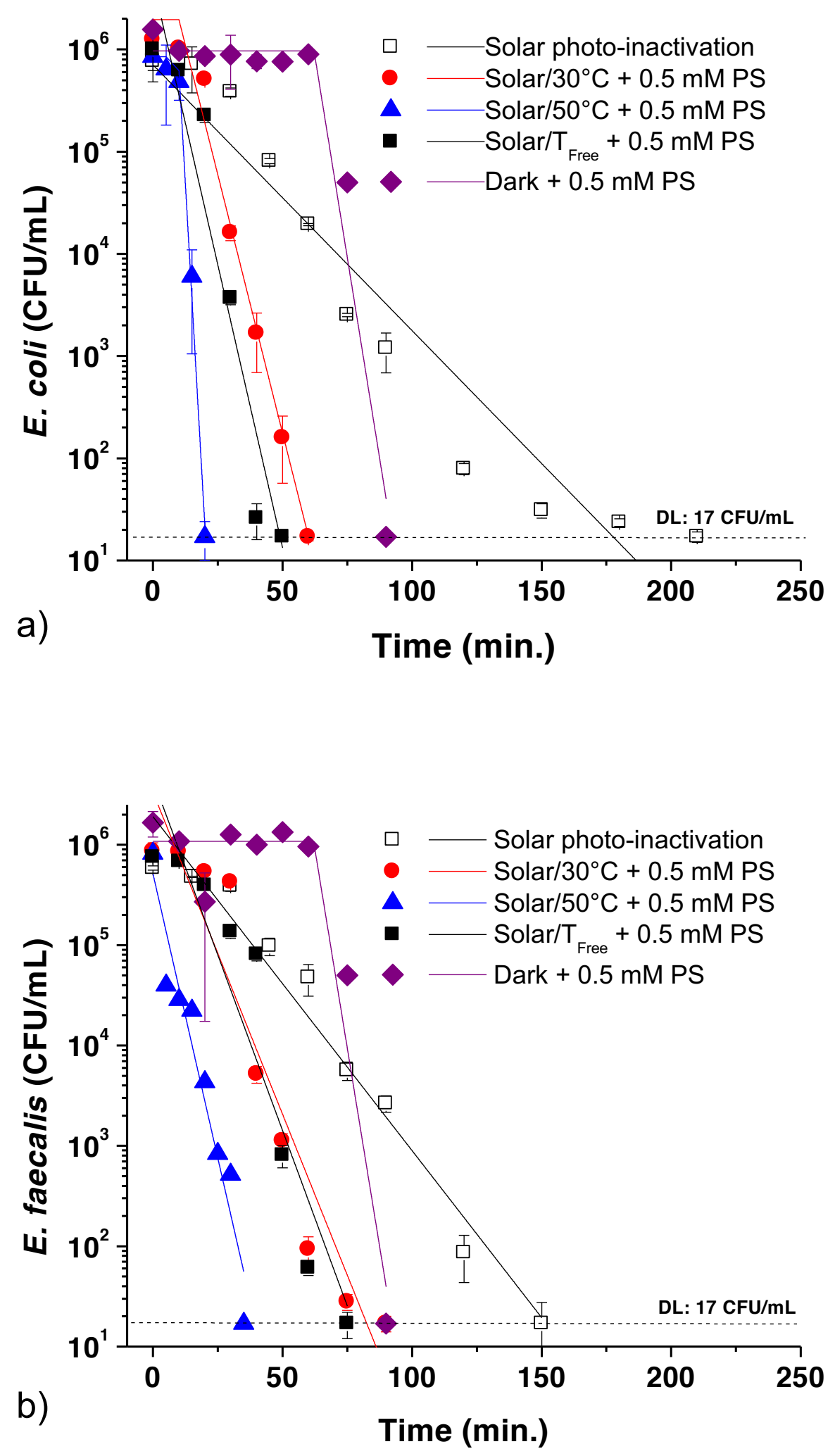

Figure 3: Influence of temperature and solar radiation on E. coli (a) and E. faecalis (b) inactivation with $0.5 \mathrm{mM}$ of PS in a solar CPC reactor in IW, at pilot scale $(60 \mathrm{~L})\left(\mathrm{T}_{\text {Free: }}: \mathrm{T}_{0 \min }=30^{\circ} \mathrm{C}, \mathrm{T}_{60 \mathrm{~min}}=39^{\circ} \mathrm{C}\right.$, $\mathrm{T}_{120 \min }=43{ }^{\circ} \mathrm{C}$ and $\left.\mathrm{T}_{180 \min }=46{ }^{\circ} \mathrm{C} ; \mathrm{T}_{\text {Dark }}=50{ }^{\circ} \mathrm{C}\right)$. 

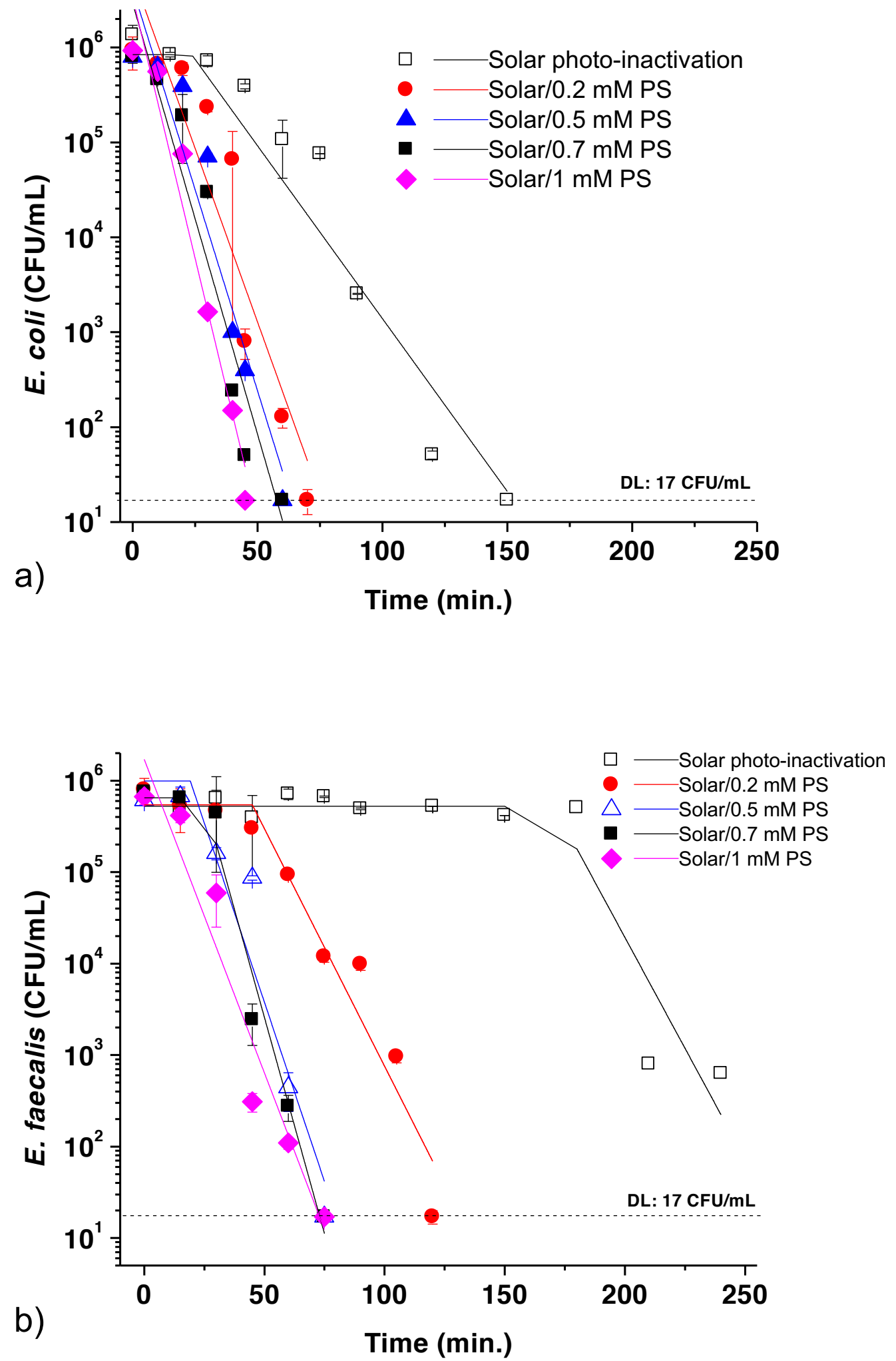

Figure 4. Inactivation of E. coli (a) and E. faecalis (b) in SUWW with several concentrations of PS under natural sunlight: $0.2,0.5,0.7$ and $1 \mathrm{mM}$ and solar only disinfection, at bench scale $\left(\mathrm{T}_{0 \mathrm{~min}}=25 \pm 2{ }^{\circ} \mathrm{C}\right.$ and $\left.\mathrm{T}_{120 \min }=35-45^{\circ} \mathrm{C}\right)$. 

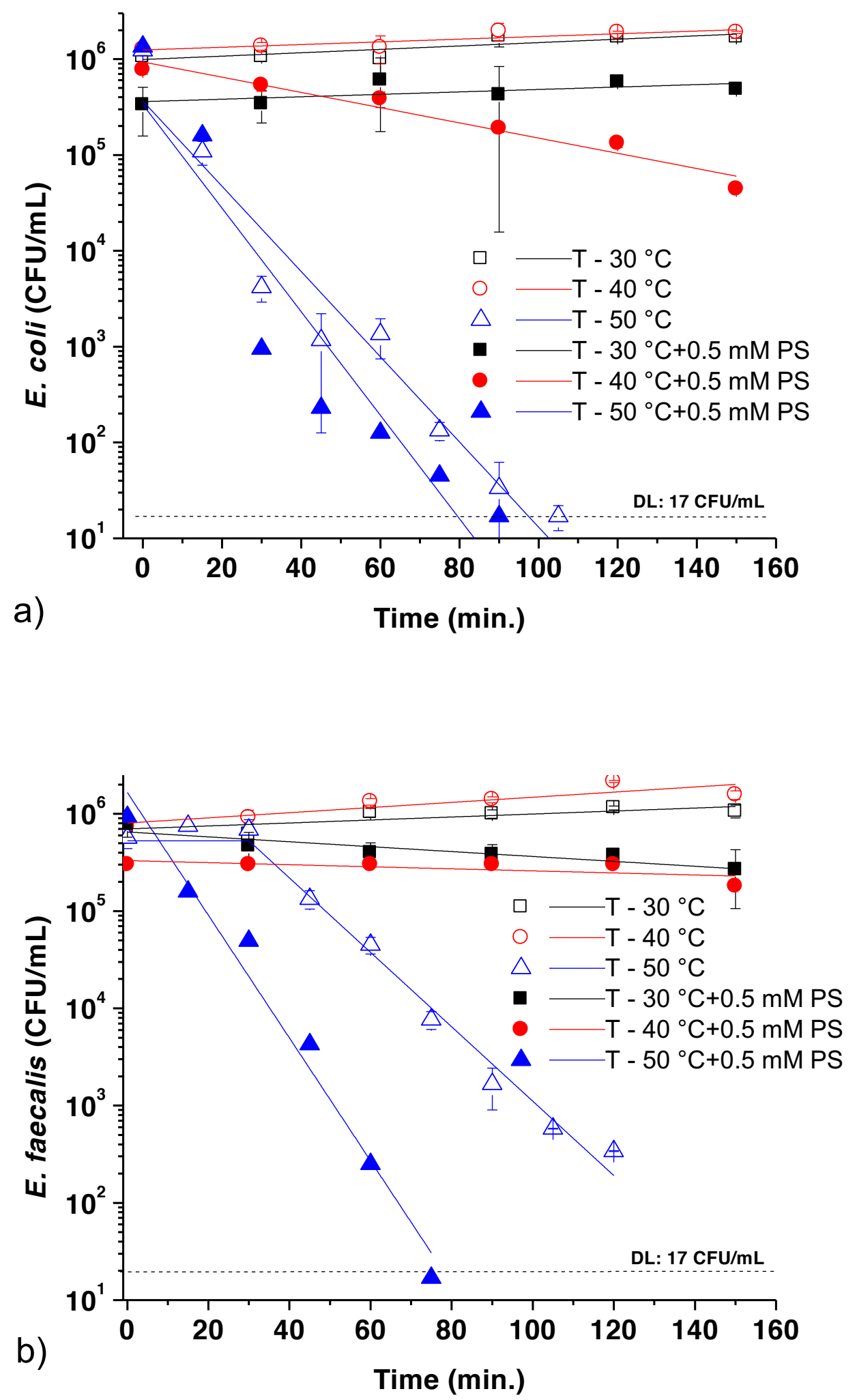

Figure 5: Influence of temperature on E. coli (a) and E. faecalis (b) inactivation and PS activation in the dark with $0.5 \mathrm{mM}$ of PS in SUWW, at bench scale. 


\begin{tabular}{|c|c|c|c|c|c|c|c|c|c|c|}
\hline \multirow[b]{2}{*}{ [PS] (mM) } & \multicolumn{5}{|c|}{ E. coli } & \multicolumn{5}{|c|}{ E. faecalis } \\
\hline & $k\left(\min ^{-1}\right)$ & $\mathbf{R}^{2}$ & $\begin{array}{c}\text { SL } \\
(\mathbf{m i n})\end{array}$ & DL & Phase & $k\left(\min ^{-1}\right)$ & $\mathbf{R}^{2}$ & $\begin{array}{c}\text { SL } \\
(\mathbf{m i n})\end{array}$ & DL & Phase \\
\hline \multicolumn{11}{|c|}{ Figure 1: Isotonic Water+ Dark + Temperature + PS } \\
\hline $30^{\circ} \mathrm{C}$ & $\mathrm{NA}^{*}$ & - & - & $\mathrm{N}$ & 2 & $\mathrm{NA}^{*}$ & - & - & $\mathrm{N}$ & 2 \\
\hline $40^{\circ} \mathrm{C}$ & NA* & - & - & $\mathrm{N}$ & 2 & $0.019 \pm 0.003$ & 0.901 & 60 & $\mathrm{~N}$ & 1 \\
\hline $50^{\circ} \mathrm{C}$ & $0.076 \pm 0.004$ & 0.984 & - & $\mathrm{Y}$ & 2 & $0.159 \pm 0.018$ & 0.960 & - & $\mathrm{Y}$ & 2 \\
\hline $30^{\circ} \mathrm{C}+0.5$ & NA* & - & - & $\mathrm{N}$ & 2 & NA* & - & - & $\mathrm{N}$ & 2 \\
\hline $40^{\circ} \mathrm{C}+0.5$ & $0.012 \pm 0.001$ & 0.937 & - & $\mathrm{N}$ & 2 & $0.023 \pm 0.003$ & 0.914 & 60 & $\mathrm{Y}$ & 1 \\
\hline $50^{\circ} \mathrm{C}+0.5$ & $0.060 \pm 0.004$ & 0.960 & - & Y & 2 & $0.091 \pm 0.015$ & 0.869 & - & $\mathrm{Y}$ & 2 \\
\hline$T_{\text {Free }}+\mathbf{0 . 5}$ & NA* & - & - & $\mathrm{N}$ & 2 & NA* & - & - & $\mathrm{N}$ & 2 \\
\hline \multicolumn{11}{|c|}{ Figure 2: Isotonic Water + Solar radiation $+P S$} \\
\hline Solar only & $0.126 \pm 0.015$ & 0.971 & 15 & $\mathrm{Y}$ & 1 & $0.060 \pm 0.004$ & 0.975 & 30 & $\mathrm{Y}$ & 1 \\
\hline 0.01 & $0.121 \pm 0.010$ & 0.979 & 15 & $\mathrm{Y}$ & 1 & $0.059 \pm 0.005$ & 0.955 & 10 & $\mathrm{Y}$ & 2 \\
\hline 0.05 & $0.168 \pm 0.015$ & 0.949 & 10 & Y & 1 & $0.060 \pm 0.005$ & 0.954 & 20 & Y & 2 \\
\hline 0.1 & $0.215 \pm 0.033$ & 0.892 & 10 & $\mathrm{Y}$ & 1 & $0.141 \pm 0.016$ & 0.964 & 40 & Y & 1 \\
\hline 0.2 & $0.191 \pm 0.017$ & 0.955 & 10 & $\mathrm{Y}$ & 1 & $0.119 \pm 0.022$ & 0.870 & 10 & $\mathrm{Y}$ & 1 \\
\hline 0.5 & $0.562 \pm 0.148$ & 0.870 & 10 & $\mathrm{Y}$ & 1 & $0.177 \pm 0.014$ & 0.981 & - & $\mathrm{Y}$ & 2 \\
\hline 0.7 & $0.554 \pm 0.280$ & 0.592 & 5 & $\mathrm{Y}$ & 1 & $0.239 \pm 0.023$ & 0.957 & - & $\mathrm{Y}$ & 2 \\
\hline
\end{tabular}

\begin{tabular}{|c|cccccc|ccccc|}
\multicolumn{10}{c|}{ Figure 3: Isotonic Water + Solar radiation+ Temperature + PS } \\
\hline Solar only & $0.026 \pm 0.002$ & 0.917 & - & $\mathrm{Y}$ & 2 & $0.033 \pm 0.002$ & 0.963 & 10 & $\mathrm{Y}$ & 1 \\
$\mathbf{3 0}{ }^{\circ} \mathbf{C}+\mathbf{0 . 5}$ & $0.101 \pm 0.006$ & 0.981 & 10 & $\mathrm{Y}$ & 1 & $0.064 \pm 0.007$ & 0.908 & 10 & $\mathrm{Y}$ & 1 \\
$\mathbf{5 0}^{\circ} \mathbf{C}+\mathbf{0 . 5}$ & $0.445 \pm 0.037$ & 0.986 & 10 & $\mathrm{Y}$ & 1 & $0.113 \pm 0.012$ & 0.924 & - & $\mathrm{Y}$ & 2 \\
$\mathbf{T}_{\text {Free }}+\mathbf{0 . 5}$ & $0.110 \pm 0.017$ & 0.891 & 10 & $\mathrm{Y}$ & 1 & $0.070 \pm 0.010$ & 0.873 & 10 & $\mathrm{Y}$ & 1 \\
Dark $+\mathbf{0 . 5}$ & $0.157 \pm 0.042$ & 0.863 & 60 & $\mathrm{Y}$ & 1 & $0.158 \pm 0.042$ & 0.868 & 60 & $\mathrm{Y}$ & 1 \\
\hline
\end{tabular}

\begin{tabular}{|c|ccccc|cccccc|}
\hline \multicolumn{10}{c|}{ Figure 4: Synthetic Wastewater + Solar radiation + PS } \\
\hline Solar only & $0.036 \pm 0.004$ & 0.912 & 30 & $\mathrm{Y}$ & 1 & $0.048 \pm 0.026$ & 0.914 & 180 & $\mathrm{~N}$ & 1 \\
$\mathbf{0 . 2}$ & $0.073 \pm 0.011$ & 0.856 & 20 & $\mathrm{Y}$ & 1 & $0.052 \pm 0.008$ & 0.898 & 45 & $\mathrm{Y}$ & 1 \\
$\mathbf{0 . 5}$ & $0.084 \pm 0.011$ & 0.897 & - & $\mathrm{Y}$ & 2 & $0.078 \pm 0.014$ & 0.880 & 15 & $\mathrm{Y}$ & 1 \\
$\mathbf{0 . 7}$ & $0.091 \pm 0.012$ & 0.899 & - & $\mathrm{Y}$ & 2 & $0.094 \pm 0.013$ & 0.942 & 30 & $\mathrm{Y}$ & 1 \\
$\mathbf{1}$ & $0.110 \pm 0.011$ & 0.945 & - & $\mathrm{Y}$ & 2 & $0.068 \pm 0.008$ & 0.926 & - & $\mathrm{Y}$ & 2 \\
\hline
\end{tabular}

\begin{tabular}{|c|c|c|c|c|c|c|c|c|c|c|}
\hline \multicolumn{11}{|c|}{ Figure 5: Synthetic Wastewater + dark + Temperature + PS } \\
\hline $\mathbf{3 0}^{\circ} \mathrm{C}$ & $\mathrm{NA}^{*}$ & - & - & $\mathrm{N}$ & 2 & $\mathrm{NA}^{*}$ & - & - & $\mathrm{N}$ & 2 \\
\hline $40^{\circ} \mathrm{C}$ & NA* & - & - & $\mathrm{N}$ & 2 & $\mathrm{NA}^{*}$ & - & - & $\mathrm{N}$ & 2 \\
\hline $50^{\circ} \mathrm{C}$ & $0.044 \pm 0.004$ & 0.935 & - & $\mathrm{N}$ & 2 & $0.038 \pm 0.002$ & 0.981 & 30 & $\mathrm{~N}$ & 1 \\
\hline $30^{\circ} \mathrm{C}+0.5$ & NA* & - & - & $\mathrm{N}$ & 2 & NA* & - & - & $\mathrm{N}$ & 2 \\
\hline $40^{\circ} \mathrm{C}+0.5$ & NA* & - & - & $\mathrm{N}$ & 2 & NA* & - & - & $\mathrm{N}$ & 2 \\
\hline $50^{\circ} \mathrm{C}+0.5$ & $0.054 \pm 0.009$ & 0.862 & - & $\mathrm{Y}$ & 2 & $0.063 \pm 0.004$ & 0.974 & 15 & $\mathrm{Y}$ & 1 \\
\hline
\end{tabular}

Model 1: Shoulder length (SL) + Log-Linear; Model 2: Log-linear;

$\mathrm{T}_{\text {Free }}$ : Laboratory temperature $\left(\sim 25^{\circ} \mathrm{C}\right)$. DL: Detection limit, Y:Yes, N: No.

* NA: no fitting, i.e. bacterial concentration was constant $\left( \pm 0.004 \mathrm{~min}^{-1}\right)$.

Table 1. The kinetic model used in each case has been selected based on the higher root mean square obtained for different models. 


\section{Inactivation of water pathogens with solar photo-activated persulfate oxidation}

L. C. Ferreira ${ }^{\mathrm{a}}$, M. Castro-Alférez ${ }^{\mathrm{b}}$, S. Nahim-Granados ${ }^{\mathrm{b}}$, M.I. Polo-López ${ }^{\mathrm{b}}$, M. S. Lucas ${ }^{\mathrm{a}, \mathrm{c}^{*}}$, G. Li Puma ${ }^{\mathrm{c}}$, P. Fernández-Ibáñez ${ }^{\mathrm{b}, \mathrm{d}}$

${ }^{a}$ Centro de Química de Vila Real, Universidade de Trás-os-Montes e Alto Douro, 5000-801 Vila Real, Portugal

${ }^{\text {b }}$ Plataforma Solar de Almería - CIEMAT, P.O. Box 22, 04200 Tabernas, Almería, Spain

c Environmental Nanocatalysis \& Photoreaction Engineering, Department of Chemical Engineering, Loughborough University, Loughborough, LE11 3TU, United Kingdom

${ }^{\mathrm{d}}$ Nanotechnology and Integrated BioEngineering Centre, School of Engineering, University of Ulster, Newtownabbey, Northern Ireland BT37 0QB, United Kingdom

\section{Supplementary Material}

*Corresponding authors:

Marco S. Lucas; mlucas@utad.pt

Pilar Fernández-Ibáñez; p.fernandez@ulster.ac.uk 


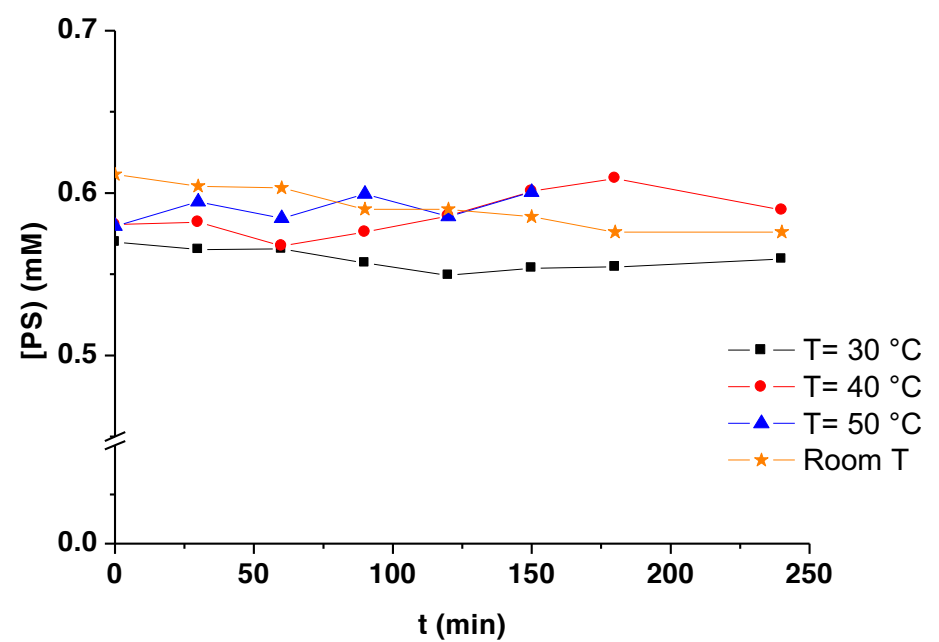

Figure S1 - PS concentration during the experiments in the dark at $30^{\circ} \mathrm{C}, 40^{\circ} \mathrm{C}$ and $50{ }^{\circ} \mathrm{C}$ with $0.5 \mathrm{mM}$ of PS.

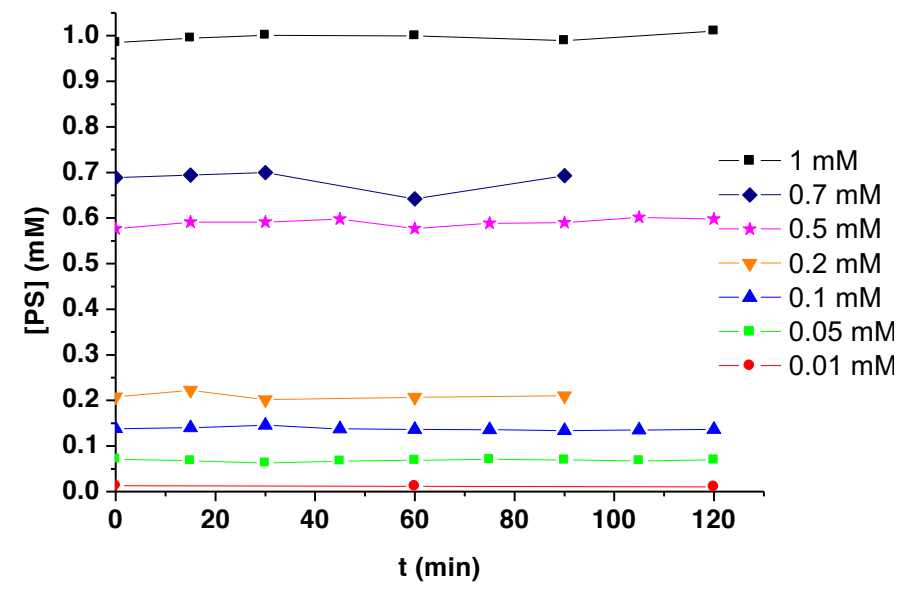

Figure S2 - PS concentration during the experiments with IW and SUWW, at different temperatures. 


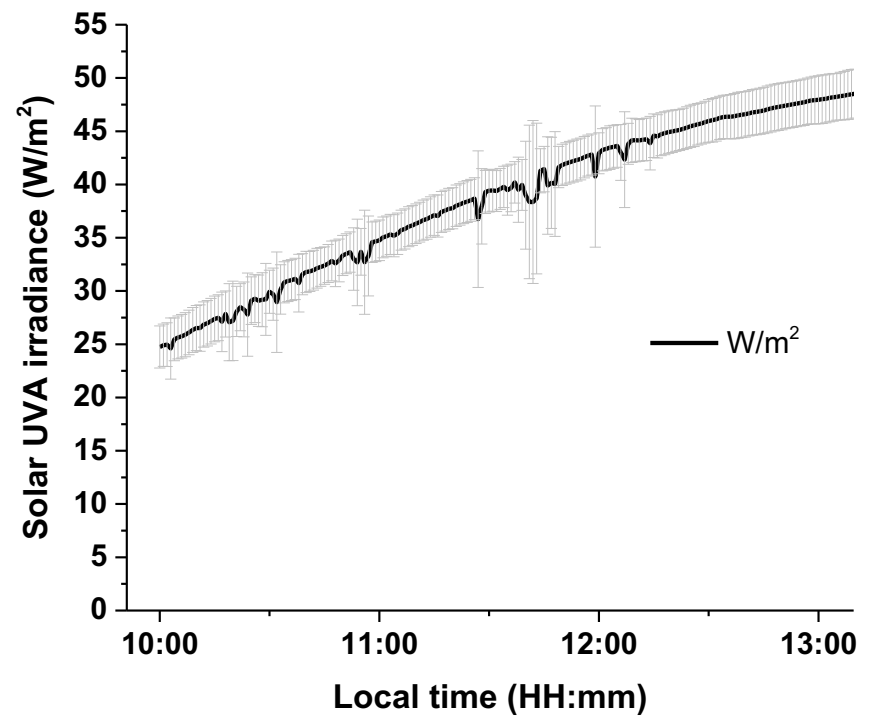

Figure S3 - Average values of solar irradiance measured during the experiments. 